\title{
Fortification of Citric Acid to Enhance Sensory Properties ofPapaya Jam during Storage
}

\author{
Dharia Renate \\ Department of Food Technology, Faculty of Agricultural Technology University of Jambi \\ Jl. Raya Jambi-Muara Bulian Km.15 Mendalo Darat Jambi, 36361, Indonesia \\ E-mail: dhariarenatelyahoo.com
}

\begin{abstract}
The objectives of this research were to know the effect of citric acid on papaya jam to its sensory properties during storage and to determine the concentration of citric acid and storage time to the quality of papaya jam. Material used was mature and ripe of fresh papaya, purchased from local market. This research was designed as a Factorial Completely Randomized Designed. The factors were the concentration of citric acids $(0.3,0.35,0.4$ percent $w / w)$ and storage times $(0,1,2,3,4$ weeks). The number of 18 trained panelists evaluated the color, texture, spreadibility and flavor. Data was analyzed using analysis of variance. The significantly different treatment was further analyzed by using Multiple Comparison and Tukey Test. The results indicated that the concentration of citric acids and storage time had significant effects on the quality of papaya jam. Research concluded that the concentration of citric acids of 0.4 percent and storage time of 2 weeks were found to yield the best quality in papaya jam. The papaya jam was good in light yellow color, soft texture, good spreadibility, liked flavor, hence the consumer acceptance like this papaya jam.
\end{abstract}

Key word--papaya jam; citric acid; storage time; sensory evaluation.

\section{INTRODUCTION}

Papaya is a popular fruit in the society with high production especially in Jambi Province. Ripe papaya can be stored in room temperature about 4 days, whereas papaya is commonly consumed in fresh form. Thus, there should be technology that can develop papaya usage. Papaya which is proceed to be jam is an alternative for new product development and the attempt of product diversification to expand the usage and economic value of papaya. Papaya fruit consist of pectin and protopectin that have function as material for jam production (Rodge and Yadlod, 2009)

Jam is a thick or semi solid food product which is made from mixture of 45 part of fruit weight and 55 part of sugar weight (Desrosier, 1988). Jams are made by cooking crushed or chopped fruits with sugar until the mixture will round up on a spoon. Jams do not hold their shape but are spreadable (Bastin, 2004). The characteristic of jam can be changed during or after the processing due to inappropriate handling and biologic effect as well. The possible quality reduction that can be done is color degradation, syneresis, crystallization and different taste.

Basically papaya has a sweet flavor, whereas appropriate amount of acid is needed for papaya jam processing to increase the consistency of jam. The right amount of acid is critical to gel formulation. With too little acid, the gel will never set. Too much acid will cause the gel to lose liquid (weep). Acid addition has important role to the quality characteristics during the storage. Acid is used to decrease the $\mathrm{pH}$ of fruit pulp because gel structure formed at low $\mathrm{pH}$. Acid that can be used is citric acid
(Fatonah, 2002). Citric acid has several advantages for food industry because of its characteristic that has 
solubility, not toxic and has liked-acid flavor. Another advantages of citric acid are as a preservative, prevention of damage to the color and aroma, keep the turbidity, oxidation resistor, sucrose inverter, dark color producer for confectionery and $\mathrm{pH}$ regulator (Winarno 1997).

The objectives of acid addition are to decrease the $\mathrm{pH}$ of jam and to avoid sugar crystallization. When the fruit acidity level is low, acid addition can increase sugar amount that undergo the inversion during the boiling. Citric acid is intermedier molecule from organic acid with crystal form or white powder. Citric acid has good solubility in water, methanol and ethanol, odorless, tastes very sour, melt when heated then burned until it become charcoal. Citric acid is contained in juices such as pineapple, orange, lemon and passionfruit. The acid is used to increase acid flavor (adjust the level of acidity) (Fatonah, 2002).

Papaya jam without citric acid can affect quality changes physically that is color degradation, quality changes chemically that is high level of $\mathrm{a}_{\mathrm{w}}$ that can cause syneresis and $\mathrm{pH}$ condition should be low to create gel form. Quality change from microbiology is microbiology contamination such as Coliform, Staphylococcus aureus, mold and leavened. Quality changes from organoleptic has impact on color, texture, aroma and flavor (SNI, 2008).

\section{MATERIALS AND METHODS}

\section{A. Materials}

Mature and ripe of fresh papaya fruit were locally purchased in traditional market and pure citric acid was obtained from Sigma Chemical Co., USA. All other chemicals used were of analytical grade and the distilled water used for processing.

\section{B. Methods}

This research was designed as a Factorial Completely Randomized Designed. The factors were the concentration of citric acids $(0.3,0.35,0.4$ percent $\mathrm{w} / \mathrm{w})$ and storage times $(0,1,2,3,4$ weeks). Fresh papaya was peeled, blended and added some water to get pulp. Pulp of flesh papaya was cooked for 25 minutes, then it was added citric acid concentration and some sugar, mixed to form gel. The papaya jam was filled in sterilized jam bottle and was pasteurized at $80-85^{\circ} \mathrm{C}$ for 30 minutes and then it was stored at room temperature (Albrecht, 2010).

\section{Sensory Evaluation}

The sensory test was subjected to citric acid treatment on papaya jam by the sensory evaluation of the quality of papaya jam. The number of 18 trained panelists evaluated the papaya jam samples by writing a check in questionnaire paper for their respond. The panelists evaluated the color, texture, spreadibility and flavor. The score of sensory evaluation test was 1-7 scale. The score of color was $7=$ extremely good, $6=$ very good, $5=$ good, $4=$ average, $3=$ bad, $2=$ very bad, $1=$ extremely poor. The score of texture was $7=$ extremely soft, $6=$ very soft, $5=$ soft, $4=$ average,
$3=$ hard, $2=$ very hard $=1=$ extremely hard. The score of spreadibility was $7=$ extremely smooth, $6=$ very smooth, $5=$ smooth, $4=$ average, $3=$ hard, $2=$ very hard, $1=$ extremely hard. The score of flavor $7=$ extremely like, $6=$ really like, $5=$ like, $4=$ average, $3=$ dislike, $2=$ do not like, $1=$ extremely dislike.

D. Data Analyzing

Data was analyzed using analysis of variance to know the differences among treatment factor. The significantly different treatment was further analyzed by using Multiple Comparison and Tukey Test.

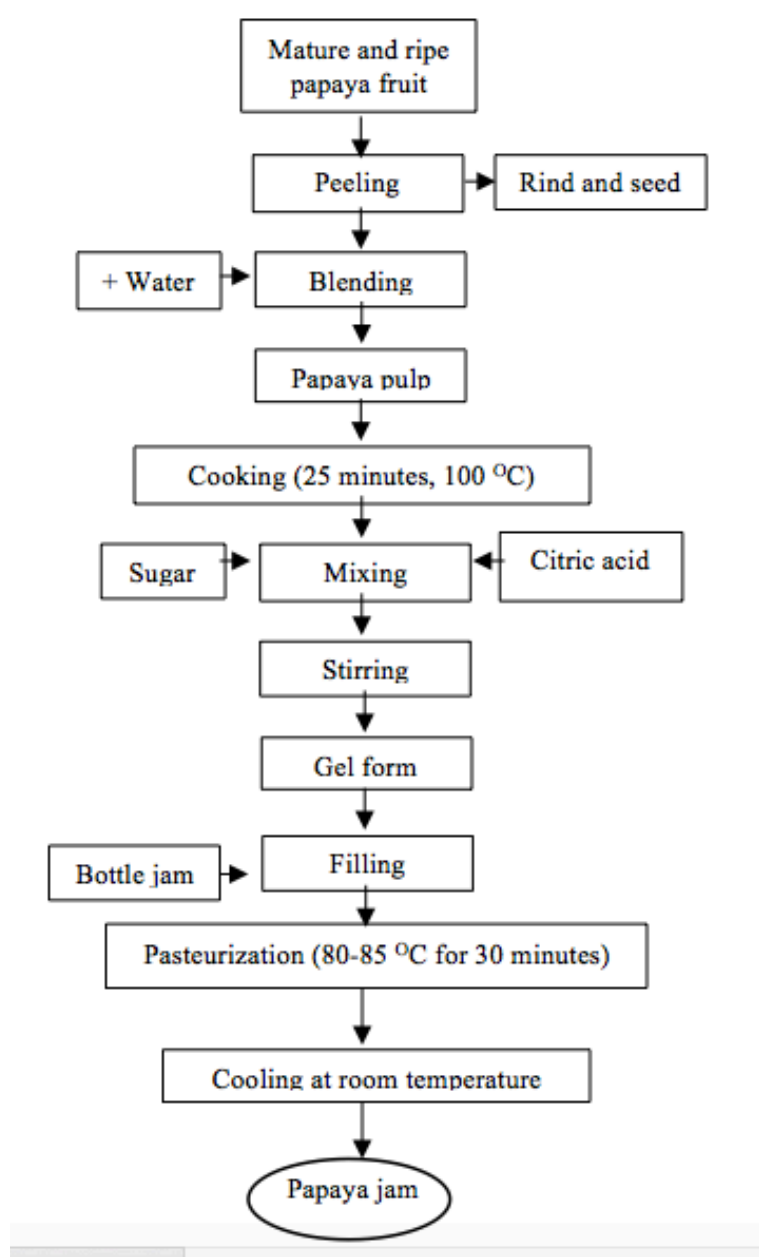

Fig.1. Processing of papaya jam

\section{RESULTS AND DISCUSSION}

In this investigation carried out to know the effect of citric acid on papaya jam to its sensory evaluation in storage and to determine the concentration of citric acid and storage time to the sensory quality of papaya jam. The results indicated that the concentration of citric acids and storage time had significant effects on the quality of papaya jam.

Table 1 showed that citric acid concentration of 0.3 percent versus 0.35 and 0.4 percent indicated the differences among the sensory evaluation value of papaya 
jam in the quality of color, texture, spreadibility and flavor with mean difference value were $-1.83,-1.76$ and -2.02 , 1.56 and -190 and -1.73 and -2.04 respectively.

The addition of citric acid will arrange $\mathrm{pH}$ of papaya jam and it also will avoid crystallization. As suquestran, citric acid bind the metal complex of material and as a result it can catalyzed and stabilize some components such as color, texture and flavor (Desrosier, 1988). The right amount of acid is critical to gel formulation. With too little acid, the gel will never set. Too much acid will cause the gel to lose liquid (weep). The concentration of citric acid of 0.3 percent added in papaya jam has not affected the quality of sensory yet.

TABLE 1

MULTIPLE COMPARISON OF CITRIC ACID CONCENTRATIONS ON PAPAYA JAM

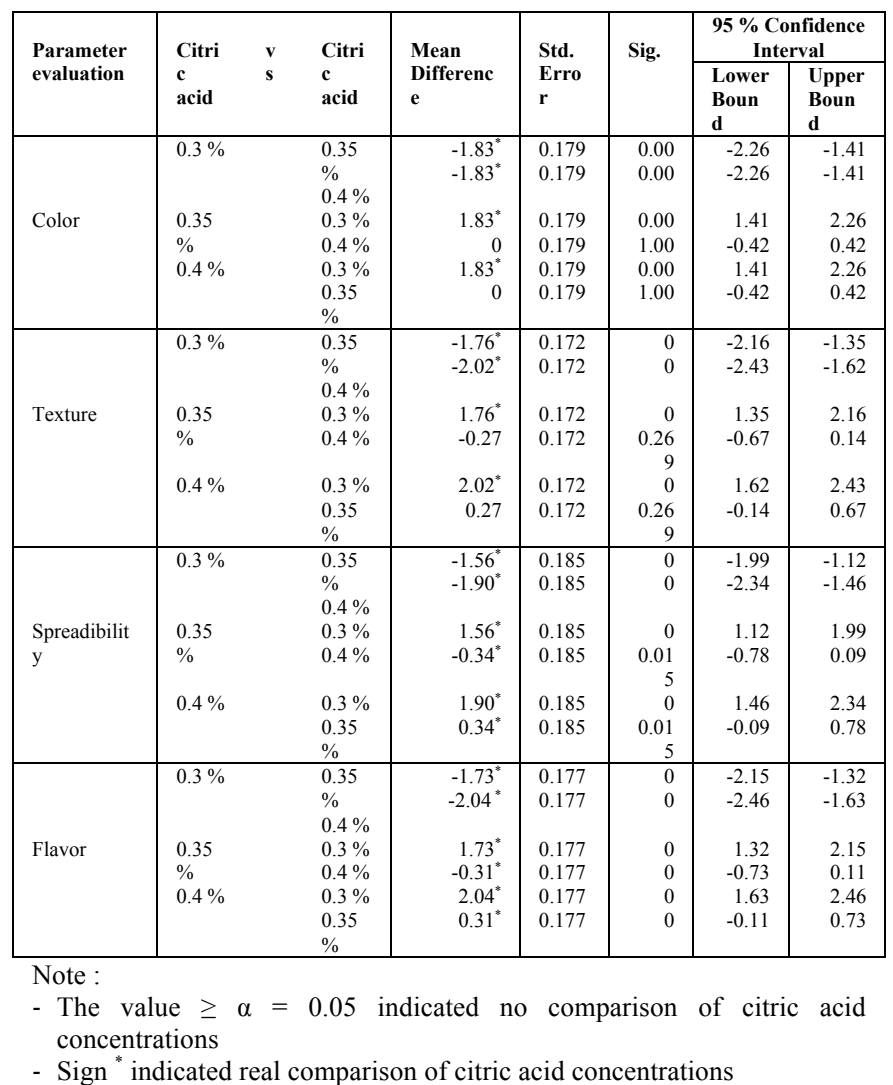

Table 2 showed that the addition of citric acid concentration of 0.30 percent on papaya jam was different from the addition of 0.35 and 0.40 percent of citric acid concentration in color, texture, spreadibility and flavor of sensory evaluation on papaya jam. With too little citric acid concentration on papaya jam can not form the gel, whereas too much citric acid will lose the liquid of papaya jam. The right concentration of citric acid will form the gel formulation. Thus, using citric acid concentration of 0.35 and 0.40 percent was found to yield best quality of papaya jam. This papaya jam was good in light yellow color, soft texture, good spreadibility and liked flavor.
TABLE 2

EFFECT OF CITRIC ACIDS TO SENSORY EVALUATION OF PAPAYA JAM

\begin{tabular}{|c|c|c|c|c|}
\hline \multirow{2}{*}{$\begin{array}{l}\text { Concentration } \\
\text { of citric acid }\end{array}$} & \multicolumn{4}{|c|}{ Sensory evaluation of papaya jam } \\
\hline & Color & Texture & Spreadibility & Flavor \\
\hline $0.30 \%$ & $3.06 \mathrm{~b}$ & $3.22 \mathrm{~b}$ & $3.24 \mathrm{~b}$ & $3.17 \mathrm{~b}$ \\
\hline $0.35 \%$ & $4.09 \mathrm{a}$ & $4.98 \mathrm{a}$ & $4.80 \mathrm{a}$ & $4.90 \mathrm{a}$ \\
\hline $0.40 \%$ & $4.89 \mathrm{a}$ & $5.24 \mathrm{a}$ & $5.14 \mathrm{a}$ & $5.21 \mathrm{a}$ \\
\hline \multicolumn{5}{|c|}{$\begin{array}{l}\text { Note : } \\
\text { - The same letter indicated no differences based on Tukey test. } \\
\text { - The number of } 1-7 \text { indicated that : } \\
\text { Color: Score } 7=\text { extremely good, } 6=\text { very good, } 5=\text { good, } 4=\text { average, } 3= \\
\text { bad, } 2=\text { very bad, } 1=\text { extremely poor } \\
\text { Texture: Score } 7=\text { extremely soft, } 6=\text { very soft, } 5=\text { soft, } 4=\text { average, } \\
3=\text { hard, } 2=\text { very hard }=1=\text { extremely hard } \\
\text { Spreadibility: Score } 7=\text { extremely smooth, } 6=\text { very smooth, } 5=\text { smooth, } \\
4=\text { average, } 3=\text { hard, } 2=\text { very hard, } 1=\text { extremely hard } \\
\text { Flavor: Score } 7=\text { extremely like, } 6=\text { really like, } 5=\text { like, } 4=\text { average, } 3= \\
\text { dislike, } 2=\text { do not like } 1=\text { extremely dislike }\end{array}$} \\
\hline
\end{tabular}

Table 3 showed that the sensory evaluation of papaya jam stored during two weeks was different from the papaya jam stored during three and four weeks in the quality of color, texture, spreadibility and flavor. Papaya jam stored for three and four weeks resulted in low score in sensory evaluation test of color, texture, spreadibility and flavor, the average quality. More over, the storage time of two weeks of papaya jam resulted in higher score of sensory evaluation test than those stored at four weeks. Thus, the papaya jam stored during two weeks was found to yield best quality of papaya jam. The sensory evaluation of color, texture, spreadibility and flavor on papaya jam was good in light yellow color, very soft, very smooth and liked, respectively. Hence, the consumer acceptance of papaya jam was really like.

TABLE 3

EFFECT OF STORAGE TIME TO SENSORY EVALUATE OF PAPAYA JAM

\begin{tabular}{|c|l|l|l|l|}
\hline \multirow{2}{*}{$\begin{array}{l}\text { Storage time } \\
\text { (weeks) }\end{array}$} & \multicolumn{4}{|c|}{ Sensory evaluation of papaya jam } \\
\cline { 2 - 5 } & Color & Texture & Spreadibility & Flavor \\
\hline 0 & $4.70 \mathrm{a}$ & $4.74 \mathrm{a}$ & $5.89 \mathrm{a}$ & $4.83 \mathrm{a}$ \\
\hline 1 & $4.56 \mathrm{a}$ & $5.07 \mathrm{a}$ & $5.19 \mathrm{a}$ & $4.76 \mathrm{a}$ \\
\hline 2 & $4.81 \mathrm{a}$ & $5.24 \mathrm{a}$ & $4.69 \mathrm{a}$ & $4.87 \mathrm{a}$ \\
\hline 3 & $3.70 \mathrm{~b}$ & $3.67 \mathrm{~b}$ & $3.63 \mathrm{~b}$ & $3.91 \mathrm{~b}$ \\
\hline 4 & $3.61 \mathrm{~b}$ & $3.69 \mathrm{~b}$ & $3.59 \mathrm{~b}$ & $3.67 \mathrm{~b}$ \\
\hline
\end{tabular}

- The same letter indicated no differences based on Tukey test.

- The number of $1-7$ indicated that :

Color: Score $7=$ extremely good, $6=$ very good, $5=$ good, $4=$ average, $3=$ bad, $2=$ very bad, $1=$ extremely poor

Texture: Score $7=$ extremely soft, $6=$ very soft, $5=$ soft, $4=$ average, $3=$ hard, $2=$ very hard $=1=$ extremely hard

Spreadibility: Score $7=$ extremely smooth, $6=$ very smooth, $5=$ smooth, $4=$ average, $3=$ hard, $2=$ very hard, $1=$ extremely hard

Flavor: Score $7=$ extremely like, $6=$ really like, $5=$ like, $4=$ average, $3=$ dislike, $2=$ do not like, $1=$ extremely dislike 


\section{CONCLUSIONS}

Research concluded that the concentration of citric acids of 0.4 percent and storage time of two weeks were found to yield the best quality in papaya jam. The papaya jam was good in light yellow color, soft texture, good spreadibility and liked flavor, hence the consumer acceptance like this papaya jam.

\section{REFERENCES}

[1] Desrosier, N. 1988. Technology of Food Preservation. AVI Publ, Co, Inc., Wesport, Connecticut.

[2] Fatonah. 2002. Teknologi Pengolahan Pangan. Penerbit Bumi Aksara. Jakarta.

[3] Rodge, B. M., and Yadlod, S. S. 2009. Evaluation of papaya varieties for jam making. The Asian $J$. Horticulture. 4(2): 267-270.

[4] Standar Nasional Indonesia (SNI). 2008. Selai Buah 3746. Penerbit Badan Standarisasi Nasional. Jakarta: 26 pages.

[5] Winarno, F.G. 1977. Kimia Pangan dan Gizi. Gramedia Pustaka Utama. Jakarta.

[6] Y, Sujatha., and Bera, Sayantan. 2014. Optimization of Ingredients in Papaya Fruit Bar. Biolife J. 2(1): 377-380. 